\title{
Alloxan Induced Diabetes and Impairment of Oxidative Defense System In Rat Pancreas : Protective Effect of Actinopteris Dichotoma
}

\author{
${ }^{1}$ P.Sailaja Rao ${ }^{2}$ Mehnoor Farheen,${ }^{3}$ Prakash V Diwan \\ ${ }^{1}$ Associate Professor, Sri Venkateshwara College of Pharmacy, Hyderabad-81, Telangana State, India \\ 2 Assistant Professor, Shadan Women's college of Pharmacy, Hyderabad-81, Telangana State, India \\ ${ }^{3}$ Professor, Maratha Mandal's Central Research Laboratory, Belgaum-590 006, Karnataka, India.
}

*Address for Correspondance: SriVenkateshwara College of Pharmacy, Madhapur, Hyderabad-81.

\begin{abstract}
:
The present study was aimed to evaluate the anti-hyperglycemic activity and in vivo anti-oxidant effect of ethyl acetate extract of Actinopteris dichotoma.It is commonly known as peacock's tail which belongs to the family Pteridaceae. Ethyl acetate extract of whole plant of Actinopteris dichotoma (EAAD) was prepared by Soxhlet extraction. Wistar rats weighing (180-200 gms) were divided into 6 groups $(n=6)$, and three doses $(100 \mathrm{mg} / \mathrm{kg}, 200 \mathrm{mg} / \mathrm{kg}$ and $400 \mathrm{mg} / \mathrm{kg}$ ) of extract were selected. Insulin was used as a standard drug. Diabetes was induced by alloxan $(120 \mathrm{mg} / \mathrm{kg}$, i.p) in control group. The animals were pre-treated with the extracts at specified doses for a period of 14 days.On $21^{\text {st }}$ day, the blood glucose levels along with antioxidant enzymes like Superoxide dismutase (SOD), Catalase (CAT) and lipid peroxidase (LPO) were also determined in all animals. Histopathological studies were also performed to observe the effect of test drug on pancreas. The EEAD at $200 \mathrm{mg} / \mathrm{kg}$ body weight showed a significant reduction in blood glucose levels $(\mathrm{p}<0.001)$ with the value of $150.6 \mathrm{mg} / \mathrm{dl}$ on $21^{\text {st }}$ day as compared to the diabetic control. Also, the extract showed significant improvement in SOD and CAT with 35.61 and $40.56 \mathrm{U} / \mathrm{mg}$ of protein. Histopatho study of pancreatic tissue exhibited normal exocrine structure with less hemorrhage or damage in endocrine portion. These results suggest that ethyl acetate extracts of Actiniopteris dichotoma Bedd at the dose of 200 $\mathrm{mg} / \mathrm{kg}$ showed anti-hyperglycemic effect with a substantial evidence of increased pancreatic cell viability as compared to the diabetic control.
\end{abstract}

KEYWORDS: Ethyl acetate, Alloxan, Blood glucose, Actinopteris dichotoma, Pancreas.

\section{INTRODUCTION:}

Diabetes mellitus is a metabolic disorder characterized by hyperglycaemia with hampered metabolism of vital biological components like carbohydrate, protein and lipids. The effects are mainly due to the defective insulin secretion, loss of insulin receptors or both. ${ }^{[1]}$ Earliercentury in India, two physicians "Charaka and Susruta" reported the disease. However, in $18^{\text {th }}-19^{\text {th }}$ century hyperglycaemia is less visualized clinically, identified by uncontrolled glycosuria and usually diagnosed in later stage of life, currently it is recognized as type 2 diabetes mellitus. Persistent higher blood glucose levels generate free radicals that may lead to the development of oxidative stress in distinct parts of the body which further culminate to various complications such as cardiovascular, neurodegenerative, chronic kidney failure, ocular damage and vascular diseases. Free radicals are highly unstable reactive oxygen species (ROS) produced regularly in various normal biological reactions in the human system. Whenever these free radicals are produced, their effects are monitored by defense system of the body which includes antioxidant enzymes like superoxide dismutase (SOD), catalase (CAT), glutathione peroxidase (GPX), glutathione reductase (GR) and lipid peroxidase (LPO). ${ }^{[2]}$ This "oxidative shielding" acts as a protective mechanism to counter the attack of toxic pathogens or noxious chemicals or to destruct the cell by apoptosis and thus preventing its advancement to neighboring cells. ${ }^{[3]}$ The term "oxidative stress" is biological state in which ROS and RNS level attain a 
${ }^{1}$ P.Sailaja Rao, International Journal of Ayurvedic \& Herbal Medicine 8(1) Jan.-Feb. 2018 (3104-3111)

maximum peak, either by excess production or insufficient removal. Since ROS and RNS have been a highly reactive molecule it will cause some alteration to vital biological proteins, carbohydrates, DNA, lipids and other molecules, further prelude to physiological dysfunction of cells and pathologic condition like diabetes, heart diseases and cancer. ${ }^{[4]}$

The use of synthetic agents is frequently associated with several undesirable side effects and fails to correct the fundamental biochemical lesion and diabetic complications. A search for a cure for diabetes mellitus continues along with traditional and alternative medicine. From the researcher's point of view, investigation on medicinal plants has gained importance. Many herbal supplements have been used for the treatment of diabetes, but the scientific evidence to support their effectiveness has only been investigated for few. New therapies are needed which control the hyperglycemic condition and prevent long-term complications. Though there are drugs which were reported to control blood glucose levels of diabetic subjects/ animal models, these failed to control complications of diabetes because of side/toxic effects such as hepatotoxicity or cardiac failure etc. Therefore, authentic evaluation is needed for herbal drug with an expectation of product efficacy, safety and therapeutic risk/benefit. Hence, the current research aims to scientifically investigate the traditionally used medicinal plants in the treatment of diabetes mellitus, their insulin secretagogue action and potent anti-oxidant effect.

Actiniopteris dichotoma, commonly known as peacock's tail, is a small shrub growing in region of Andhra Pradesh particularly in all districts of the state on slopes of hills specially on northern aspect. It is used as an anthelmintic, hemostatic, antileprotic action and has hypocholesterolemic effects. It is assumed to possess nutritive and restorative properties and has been used in folk medicine for centuries for a wide range of diseases including diabetes, fever and abdominal colic as a poultice for abscesses, boils. However, no report is available on the effect of the plant in the alloxan-induced diabetic Wister rats. Hence, in the present study the animals were pretreated with ethyl acetate extract of Actiniopteris dichotomain alloxan-induced diabetic rats. The histopathological studies of pancreatic tissue were also studied and the effect of drug was analyzed. [5]

\section{MATERIALS AND METHODS:}

Collection of Plant material and preparation of extract: [6]

The plant Actinopteris dichotoma was procured from Tirumala Hills, Tirupati and was authenticated by Dr. MadhavaChetty, Botanist, Sri Venkateshwara University, Tirupati, Andhra Pradesh. The plant material was powdered and extracted with ethylacetate in a soxhlet apparatus at a temperature of $60^{\circ} \mathrm{C}$ for $12 \mathrm{hrs}$. The resultant extract was filtered, and the filtered extract was then concentrated to dryness in a rotary evaporator under reduced pressure and stored in a desiccator.

\section{Preparation of Drug solution:}

An ethyl acetate extract (100 mg/kg, $200 \mathrm{mg} / \mathrm{kg}$ and $400 \mathrm{mg} / \mathrm{kg}$ body weight) of whole plant of A.dichotoma was dissolved in appropriate amount of distilled water and were administered to the rats according to the body weight.

\section{Preliminary Phytochemical analysis:}

The EEAD was screened for the presence of various phytoconstituents like alkaloids, carbohydrates, phenolics, flavonoids, glycosides and tannins.

\section{Acute toxicity study:}

Wistar rats weighing between 150 - 180 gms were selected to ascertain the toxicity range of the test drug Actinopteris dichotoma. The acute toxicity study for EEAD (Ethyl acetate extract of Actinopteris dichotoma) was done according to the OECD guide lines No. 423. ${ }^{[7]}$ The extract did not show any noticeable signs of toxicity when given in doses up to $2000 \mathrm{mg} / \mathrm{kg}$ by an oral route. Hence, for further studies two doses 100 , $200 \& 400 \mathrm{mg} / \mathrm{kg}$ body weight were selected.

\section{Animals:}

Male Wistar rats weighing about 180-250 gms obtained from National Institute of Nutrition, Hyderabad. They were kept in quarantine for acclimatization in the animal house of Sri Venkateshwara College of 
${ }^{1}$ P.Sailaja Rao, International Journal of Ayurvedic \& Herbal Medicine 8(1) Jan.-Feb. 2018 (3104-3111)

Pharmacy in animal cages at the ambient temperature of $22^{0} \mathrm{C}+2^{0} \mathrm{C}$ and relative humidity with $12 \mathrm{hr}$ each of dark and light cycles and were fed pelleted diet and water ad libitum. The experimental protocol was duly approved by IAEC (Institutional Animal Ethical Committee) of CPCSEA (Committee for purpose of control and supervision of Experimentation on animals) through its reference no: IAEC/SVCP/2016/003, Dated: 27/2/16.

\section{Alloxan induced diabetes:}

A freshly prepared solution of alloxan $(120 \mathrm{mg} / \mathrm{kg}$ in $0.1 \mathrm{M}$ citrate buffer, $\mathrm{pH} 4.5)$ was injected intraperitonially to overnight-fasted rats. The blood glucose levels were measured after $48 \mathrm{hrs}$ of alloxan administration. ${ }^{[8]}$ The rats having blood glucose levels $>200 \mathrm{mg} / \mathrm{dl}$ were selected for the study.

\section{Experimental design:}

The experiment was carried out in six groups of six rats each:

Group I- Normal control rats received saline

Group II- Diabetic control

Group III- Diabetic rats treated with standard drug, Insulin (2 units/day)

Group IV - Diabetic rats pre-treated with EEAD $(100 \mathrm{mg} / \mathrm{kg})$

Group V - Diabetic rats pre-treated with EEAD $(200 \mathrm{mg} / \mathrm{kg})$

Group VI - Diabetic rats pre-treated with EEAD (400 mg/kg)

The animals were pre-treated with the extracts at specified doses for a period of 14 days for groups IV, V and VI. Then, the diabetes was induced with alloxan and the blood was withdrawn from retro orbital plexus and centrifuged, serum glucose levels were estimated on $1^{\text {st }}, 7^{\text {th }}, 14^{\text {th }}$ and $21^{\text {st }}$ day(days considered after 14 days in groups IV, V and VI) by Glucose oxidase method and absorbance was measured at $505 \mathrm{~nm}$ by UVSpectrophotometer. ${ }^{[9]}$ At the end of the experimental period, the animals were deprived of food overnight and sacrificed by decapitation. The liver was removed and homogenized for in vivo antioxidant activity. The pancreatic tissue was dissected out, washed in ice-cold saline, patted dry, weighed snap-frozen in liquid nitrogen and finally preserved at $-80^{\circ} \mathrm{C}$ until further analysis.

\section{In vivo anti-oxidant activities:}

Lipid Peroxidation is based on the reaction of Malondialdehyde (MDA) one of the products of lipid peroxidation with thiobarbituricacid to form Thiobarbituric acid reactive substances (TBARS), which has a pink color with absorption maxima at $540 \mathrm{~nm} .{ }^{[10]}$ Catalase (CAT) activity was determined according to the method of Aebi. ${ }^{[11]}$ Superoxide dismutase (SOD) activity was determined calorimetrically by the method of Kono. ${ }^{[12]}$

\section{Statistical Analysis:}

The results are expressed as MEAN \pm SD. Comparison between the groups was made by analysis of variance (ANOVA), followed by Dunnett's test as per suitability. $\mathrm{P}<0.001$ was considered significant. Statistical calculations were done using GraphPad prism version 6.0.

From ancient times, diabetic patients have used medicinal plants to maintain blood glucose level. In this regard, the present study was extended to show the influence of Actinopteris dichotoma extracts on the blood glucose levels, oxidative stress, liver and pancreas. 
${ }^{1}$ P.Sailaja Rao, International Journal of Ayurvedic \& Herbal Medicine 8(1) Jan.-Feb. 2018 (3104-3111)

Table 1: Effect of ethylacetate extract of A.dichotoma (EEAD) on blood glucose level in diabetic rats.

\begin{tabular}{|c|c|c|c|c|c|}
\hline Groups & $\begin{array}{c}\text { Treatment } \\
\text { and dose } \\
(\mathbf{m g} / \mathbf{k g})\end{array}$ & $\mathbf{1}^{\text {st }}$ day & $\mathbf{7}^{\text {th }}$ day & $\mathbf{1 4}^{\text {th }}$ day & $\mathbf{2 1}^{\text {st }}$ day \\
\hline I & Control & $86.58 \pm 0.31$ & $87.5 \pm 0.20$ & $90.6 \pm 0.22$ & $87.5 \pm 0.26$ \\
\hline II & $\begin{array}{c}\text { Diabetic } \\
\text { control (DC) }\end{array}$ & $252.9 \pm 0.24^{\mathrm{a}}$ & $258.3 \pm 0.34^{\mathrm{a}}$ & $268.2 \pm 0.17^{\mathrm{a}}$ & $278.3 \pm 0.24^{\mathrm{a}}$ \\
\hline III & $\begin{array}{c}\text { DC }+ \text { Insulin } \\
(2 \text { Units/day) }\end{array}$ & $218.2 \pm 0.31^{\mathrm{b}}$ & $155.9 \pm 0.07^{\mathrm{b}}$ & $128.2 \pm 0.21^{\mathrm{b}}$ & $120.9 \pm 0.15^{\mathrm{b}}$ \\
\hline IV & $\begin{array}{c}\text { DC+ EEAD } \\
(100)\end{array}$ & $219.3 \pm 0.35^{\mathrm{b}}$ & $200.5 \pm 0.16^{\mathrm{b}}$ & $185.6 \pm 0.36^{\mathrm{b}}$ & $175.2 \pm 0.15^{\mathrm{b}}$ \\
\hline V & $\begin{array}{c}\text { DC+EEAD } \\
(200)\end{array}$ & $218.6 \pm 0.19^{\mathrm{b}}$ & $168.2 \pm 0.21^{\mathrm{b}}$ & $162.3 \pm 0.29^{\mathrm{b}}$ & $150.6 \pm 0.187^{\mathrm{b}}$ \\
\hline VI & $\begin{array}{c}\text { DC+EEAD } \\
(400)\end{array}$ & $220.3 \pm 0.25^{\mathrm{b}}$ & $188.6 \pm 0.27^{\mathrm{b}}$ & $180.5 \pm 0.30^{\mathrm{b}}$ & $169.3 \pm 0.19^{\mathrm{b}}$ \\
\hline
\end{tabular}

The data are expressed in Mean \pm S.E.M; $n=6$ in each group; ${ }^{b} p<0.001$, significant, compared to diabetic control

Table 1: Effect of ethylacetate extract of A.dichotoma (EEAD) on anti-oxidant enzymes in diabetic rats.

\begin{tabular}{|c|c|c|c|c|}
\hline Groups & $\begin{array}{c}\text { Treatment } \\
\text { and dose } \\
(\mathbf{m g} / \mathbf{k g})\end{array}$ & SOD & CAT & MDA \\
\hline I & Control & $56.5 \pm 0.31$ & $51.17 \pm 0.39$ & $14.34 \pm 0.34$ \\
\hline II & $\begin{array}{c}\text { Diabetic } \\
\text { control (DC) }\end{array}$ & $17.67 \pm 0.59^{\mathrm{a}}$ & $20.25 \pm 0.33^{\mathrm{a}}$ & $46.33 \pm 0.32^{\mathrm{a}}$ \\
\hline III & $\begin{array}{c}\text { DC + Insulin } \\
(2 \text { Units/day) }\end{array}$ & $48 \pm 0.17^{\mathrm{b}}$ & $49.17 \pm 0.33^{\mathrm{b}}$ & $18 \pm 0.32^{\mathrm{b}}$ \\
\hline IV & $\begin{array}{c}\text { DC+ EEAD } \\
(100)\end{array}$ & $20.38 \pm 0.23^{\mathrm{b}}$ & $17.8 \pm 0.30^{\mathrm{b}}$ & $40.8 \pm 0.24^{\mathrm{b}}$ \\
\hline V & $\begin{array}{c}\text { DC+ EEAD } \\
(200)\end{array}$ & $40.56 \pm 0.20^{\mathrm{b}}$ & $35.61 \pm 0.32^{\mathrm{b}}$ & $20.6 \pm 0.27^{\mathrm{b}}$ \\
\hline VI & $\begin{array}{c}\text { DC+ EEAD } \\
(400)\end{array}$ & $30.33 \pm 0.40^{\mathrm{b}}$ & $20.4 \pm 0.26^{\mathrm{b}}$ & $32.9 \pm 0.30^{\mathrm{b}}$ \\
\hline
\end{tabular}

The data are expressed in Mean \pm S.E.M; $n=6$ in each group; ${ }^{b} p<0.001$, significant, compared to diabetic control

Diabetes was induced with alloxan, since it was more economical and easily available. Moreover, alloxan was reported to produce diabetes by damaging pancreas by free radical related mechanisms. The diabetogenic agent alloxan has two distinct pathological effects interfering with the physiological function of the pancreatic cells. It causes a state of insulin-dependent diabetes mellitus through its ability to induce a selective necrosis of beta cells. It enters via low affinity GLUT 2, glucose transporter in the plasma membrane. Alloxan can generate "Reactive oxygen species" (ROS), the beta cell toxic action of alloxan is initiated by free radicals formed in this redox reaction. 
${ }^{1}$ P.Sailaja Rao, International Journal of Ayurvedic \& Herbal Medicine 8(1) Jan.-Feb. 2018 (3104-3111)

Preliminary Phytochemical Investigation: The preliminary phytochemical investigation of EEAD showed the presence of alkaloids, carbohydrates, phenolics, flavonoids, glycosides and tannins.

Acute toxicity studies: The acute toxicity study for EEHL was done according to the OECD guidelines No. 423. The extract did not show any noticeable signs of toxicity when given in doses up to $2000 \mathrm{mg} / \mathrm{kg}$ by an oral route. Hence, for further studies three doses 100, $200 \& 400 \mathrm{mg} / \mathrm{kg}$ body weight were selected.

\section{Effect on blood glucose levels:}

The present investigation reveals that alloxan challenged rats displayed a significant elevation $(\mathrm{p}<0.001)$ in the mean serum glucose levels on $1^{\text {st }}, 7^{\text {th }}, 14^{\text {th }}$ and $21^{\text {st }}$ days respectively. The untreated and treated rats were determined with blood glucose levels after 2 hours' period in all animals. Groups IV, V and VI were pretreated with the test extracts for 14 days, and then induced with diabetes. When the blood glucose levels were measured, it was found that there was a significant reduction of blood glucose levels from $7^{\text {th }}$ day onwards as compared to diabetic control. Amongst all the three doses of 100, 200 and $400 \mathrm{mg} / \mathrm{kg}$, dose of $200 \mathrm{mg} / \mathrm{kg}$ showed more significant decreased blood glucose levels as compared to other doses.

\section{Effect on anti-oxidative enzymes:}

In diabetes, due to the generation of free radicals, there is tissue damage due to the formation of lipid peroxides. $^{[13]}$ With the treatment of seed extract a significant decrease in lipid peroxidation and improvement of anti-oxidant status were observed which may contribute to the prevention of diabetic complications. The lipid peroxidation induced by diabetes displays a substantial decrease in the level of prime antioxidant enzymes like SOD and CAT. These biomolecules have significant function in quenching the free radicals and dysfunction the toxic adducts formation during the lipid peroxidation process. On the other hand, depleted level of antioxidant enzymes may prelude to an elevated level of noxious superoxide anion $\left(\mathrm{O}_{2}^{-}\right)$and hydrogen peroxide in the vital tissues. These radicals prelude to release hydroxylradicals, resulting in initiation and propagation of lipid peroxidation. The present study indicated a significant reduction in lipid peroxides which could be due to the presence of flavonoids, that accord to the anti-oxidant property of the plant. Decreased levels of SOD and CAT in diabetic rats may be due to the inactivation caused by reactive oxygen species. A marked depletion in SOD activity could be due to the accumulation of $\mathrm{H}_{2} \mathrm{O}_{2}$ or by glycation enzyme, whereas reduction in CAT activity could result due to chronic exposure to $\mathrm{H}_{2} \mathrm{O}_{2}$ in vivo. Pre-treatment with the extract of A.dichotoma for 14 days augmented the levels of anti-oxidant enzymes SOD and CAT significantly which may be due to the presence of polyphenolic compounds. Such anti-oxidant properties of polyphenols could be ascribed to the property of scavenging of free radicals, but also by the modulation of the mitochondrial function which represents the major cellular source of ROS. ${ }^{[14]}$ In this context, the anti-diabetic potential of EEAD might be because of bioactive principles like flavonoids, steroids, tannins, glycosides and triterpenoids which have also contributed to the effective radical scavenging property present in the plant.

Histopathological studies of tissue organs liver and pancreas were undertaken and were found that there is regeneration of toxic effect of alloxan. Alloxan administration led to the shrinkage of normal architecture of pancreatic islets which ultimately resulted in cell necrosis, apoptosis and inflammation of liver as compared to the control group in which hepatocytes of liver and beta cells of pancreas appeared normal. The pretreated diabetic rats of group V (200 mg/kg body weight) have shown mild foci of inflammation in liver. The pancreatic islets appeared normal with moderate proliferation. The groups IV and VI have shown mild inflammation and hemorrhage in the liver, while pancreas was evident with mild to massive proliferation. The EEAD extract at the dose of $200 \mathrm{mg} / \mathrm{kg}$ body weight showed recovered architecture of pancreatic islets. Alloxan induces damage to $\beta$-cell DNA, mitochondria, lysosomes and plasma membrane. 
${ }^{1}$ P.Sailaja Rao, International Journal of Ayurvedic \& Herbal Medicine 8(1) Jan.-Feb. 2018 (3104-3111)

It was noted that the destruction of $90 \%$ insulin secreting $\beta$ cells of islets of Langerhans was caused by alloxan and hence high blood glucose levels were detected.

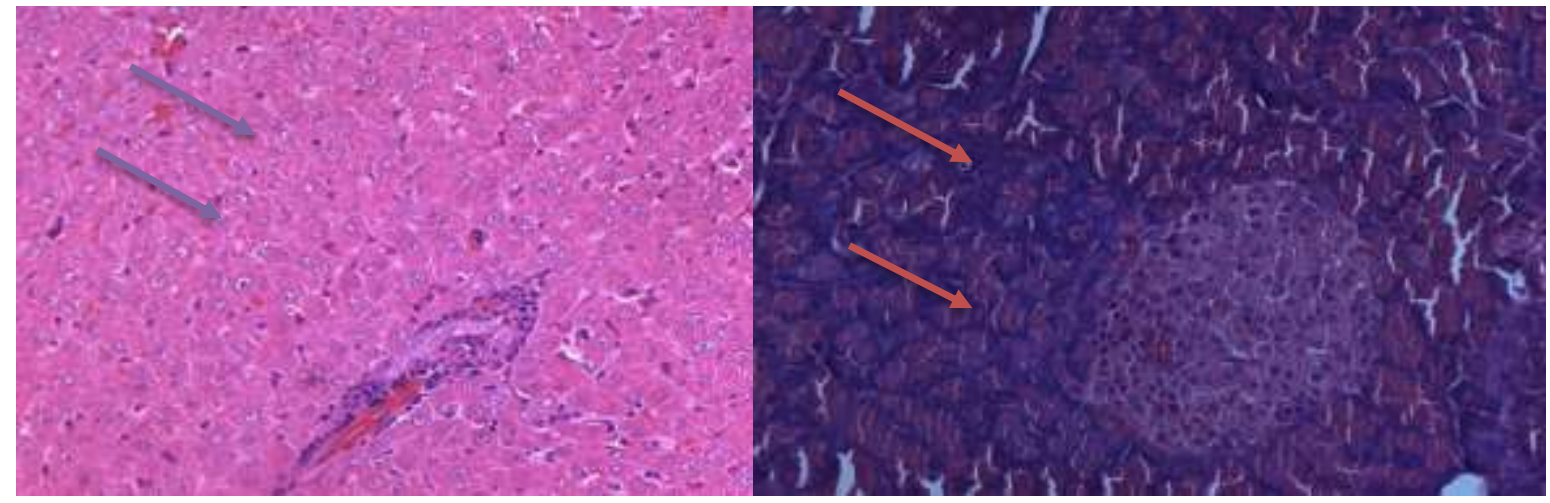

G I (A)

G I (B)

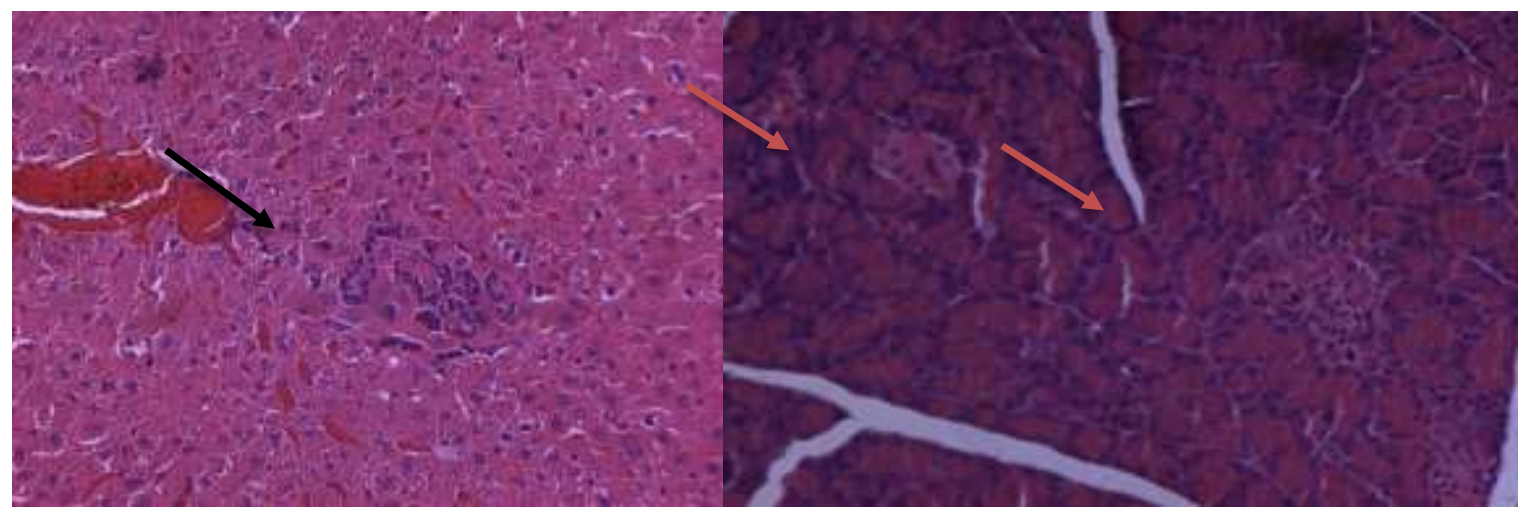

G II (A)

G II (B)

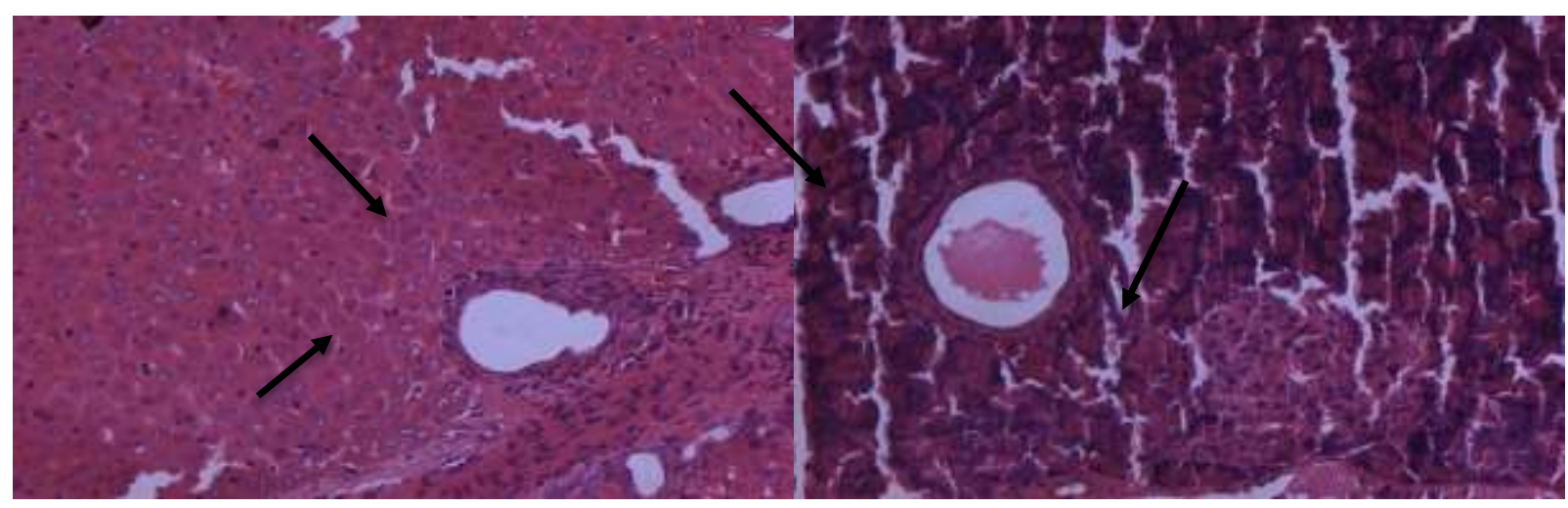

G III (A)

G III (B)

Figure 1: Histopathological examination of Liver and Pancreas

G I (A, Liver) - Individual hepatocytes appeared normal in portal, periportal and centri lobular region in liver

G I (B, Pancreas) - Beta cells in glandular pancreas (Islets of pancreas) appeared normal. Acinar cells in non-glandular pancreas appeared normal

G II (A, Liver) - Foci of inflammation noticed in centrilobular region of liver

G II (B, Pancreas) - Individual beta cell necrosis (or) apoptosis leads to atrophy of glandular pancreas

G III (A, Liver) - Moderate fibrosis (Proliferation of fibrous tissue noticed in peribiliary and portal region of liver)

G III (B, Pancreas) - Islets appear normal but found few apoptotic islets cells. Acinar cells in non-glandular region appear normal 


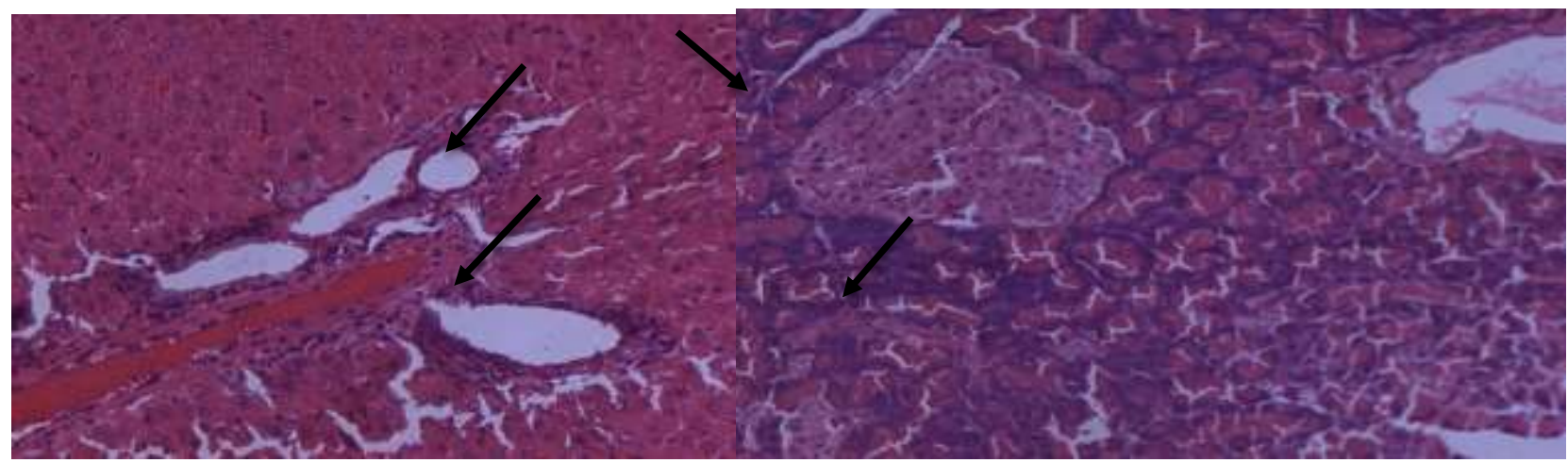

G IV (A)

G IV (B)

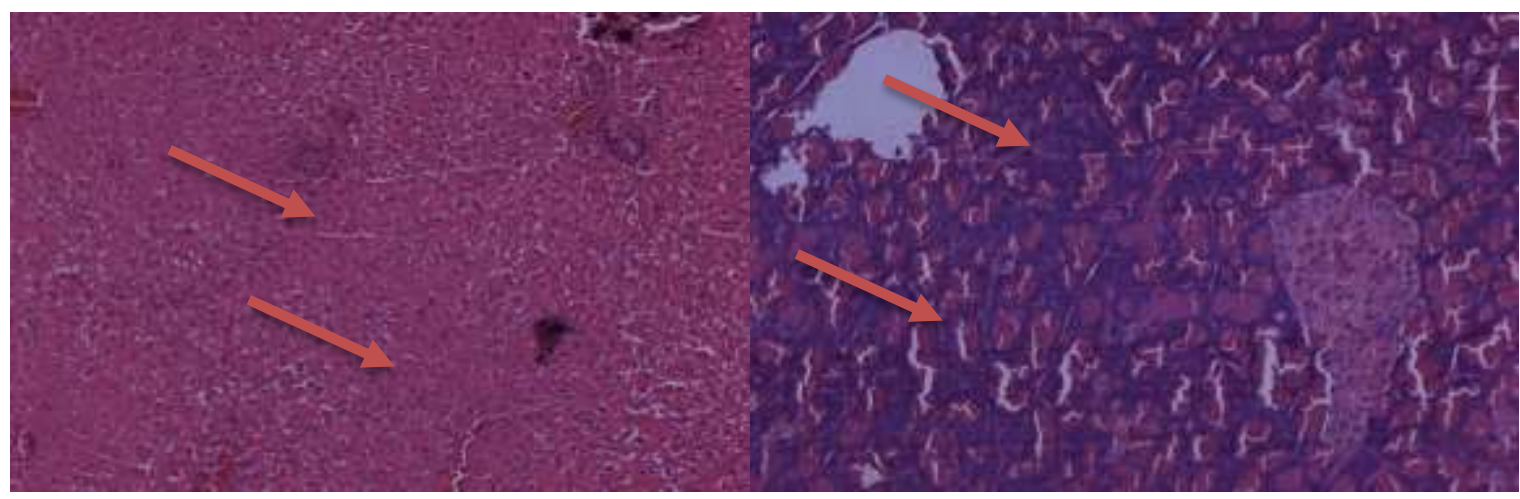

G V (A)

G V (B)

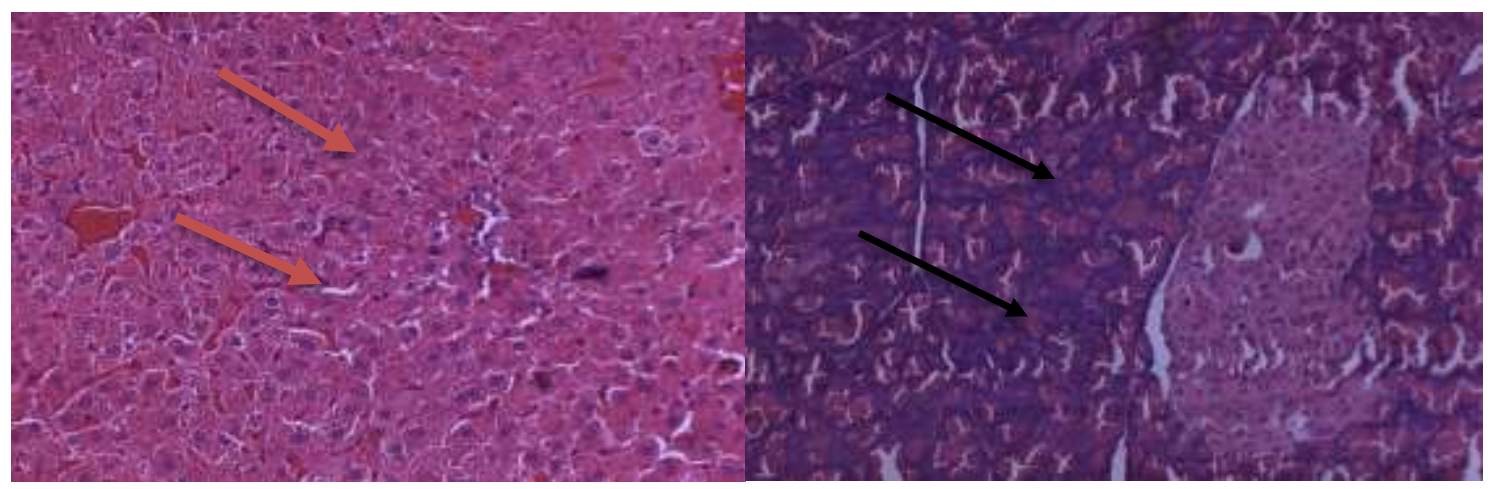

G VI (A)

G VI (B)

Figure 2: Histopathological examination of Liver and Pancreas

G IV (A, Liver) - Mild proliferation of connective tissue in portal region

G IV (B, Pancreas) - Islet cells appeared normal and mild proliferation noticed in the glandular pancreas indicates the reaction against any damage

G V (A, Liver) - Mild foci of inflammation noticed in centrilobular region of liver

G V (B, Pancreas) - Islet cells are normal and moderate proliferation of islet cells noticed as positive response

G VI (A, Liver) - Individual hepatocytes appeared normal. Mild sinusoidal hemorrhages noticed

G VI (B, Pancreas) - Massive proliferation of islets indicates positive response against any damage

The test extract $(200 \mathrm{mg} / \mathrm{kg})$ might aid in the recovery of $\beta$ cells to secrete insulin, thereby decreasing the blood glucose levels significantly. Hence, the findings showed that there was a regeneration and protection of pancreatic cells against the damage that occurred due to alloxan. Also, there was normal exocrine structure, with the evidence of viability in pancreatic cells. The preservative action of the extract might enable to prevent the occurrence of diabetes. 


\section{${ }^{1}$ P.Sailaja Rao, International Journal of Ayurvedic \& Herbal Medicine 8(1) Jan.-Feb. 2018 (3104-3111) CONCLUSION:}

This study investigated the effect of alloxan on a $\beta$ cells and threw light on the potential of ethyl acetate extract of Actinopterisdichotoma $(200 \mathrm{mg} / \mathrm{kg})$ in the prevention or treatment of diabetes. The result of this study showed that A.dichotoma brings significant reduction in the blood glucose levels, also improved the framework of pancreas. At the specified dose, the extract significantly increased the anti-oxidant status, hence protecting the tissue from oxidative damage and helps in combating the complications of diabetes. The pre-treatment with the extract might reduce the prospect of occurrence of diabetes. It exhibited defensive mechanism in resisting the damage of architecture of $\beta$-cells and hepatocytes. Although the exact natural compounds responsible for the anti-hyperglycemic effect of plant extract remains speculative, experimental evidence obtained from this study indicated that Actinopterisdichotoma possess anti-diabetic property, which also was confirmed by histopathological examination.

\section{ACKNOWLEDGEMENT}

Authors are thankful to Principal Dr. Bhagavan Raju, Sri Venkateshwara College of Pharmacy, for support, encouragement. Also, the authors thank Shadan Women's College of Pharmacy, for providing facilities to carry out the work and Osmania University, Hyderabad who extended their support for project.

\section{REFERENCES}

1. World Health Organization. Global Report on Diabetes. Diabetes Mellitus - epidemiology, prevention and control, Diabetes and Gestational. Geneva; 2016.

2. Jyothi S G, Chavan S C S, Somashekaraiah B V. In vitro and in vivo antioxidant and anti-diabetic efficacy of Cassia auriculata L. Flowers. Global Journal of Pharmacology. 2012; 6:33-40.

3. Naviaux R K. Oxidative Shielding or Oxidative Stress? J Pharmacol Exp Ther. 2012; 342 (3): 608618.

4. Rochette L, Zeller M, Cottin Y, Vergely C. Diabetes, oxidative stress and therapeutic strategies. Biochimica et Biophysica Acta - General Subjects. 2014; 9: 2709-2729.

5. Walvekar M V, Potphode N D, Desai S S, Deshmukh V M. Histological Studies on Islets of Langerhans of Pancreas in Diabetic Mice after curcumin Administration. 2016; 8(9): 1314-1318.

6. Amos Babu J, Kiran G, Sudhakar babu A M S, Venkateshwar Rao P. Anti-diabetic activity of Actinopterisdichotoma (Kuhn) leaves extracts in alloxan induced diabetic rats. International Journal of Phytopharmacology. 2012; 3(3): 308-317.

7. OECD guidelines for testing of chemicals. Acute Oral Toxicity-Acute Toxic Class Method 423.2001: 1-14.

8. Bhattacharya, Das. Anti-diabetic activity of Lagenariasiceraria pulp and seed extract in normal and alloxan-induced diabetic rats. International Journal of Pharmaceutical sciences and Research. 2012; 3(9): 3362-3369.

9. Parthiban P, Ravikumar J A, Anjana A. Anti-diabetic activity of Kovaikizhangu chooranam in alloxan induced diabetic rats. International Journal of Life Science \& Pharma Research. 2012; 2(4): 68-72.

10. Hagino H, Shiik Y K, Mastuba H. Enzyme linked immunosorbent assay method for human autophosphorylated insulin receptor: Applicability to insulin-resistant states. Diabetes. 1994; 43: 274-80.

11. Okhawa H, Ohishi N, Yagi K. Assay for lipid peroxides in animal tissue by Thiobarbituric acid reaction. AnnalBiochem. 1979; 95: 351.

12. Aebi H. Catalase. In Bergmeyer Hu (ed) Methods in enzymatic analysis. Academic press: New York. 1983; 276-286.

13. Rupesh kumar M, Kavitha K, Haldar PK.: Hypoglycemic effect of Andrographisechioides on streptozotocin induced experimental rats. J App Pharm 2015; 7: 60-68.

14. Loizzo M R, Rashed K, Said A, Bonesi M, Menichini F, Tundis R. Anti-proliferative and antioxidant properties of AlhagimaurorumBoiss (Leguminosae) aerial parts. Industrial Crops and Products. 2014; 53: 289-295. 